\title{
THE DEVELOPMENT OF LEADING FOOD COMMODITIES BASED ON LOCAL WISDOM IN FOOD-INSECURE AREA IN EAST NUSA TENGGARA PROVINCE, INDONESIA
}

\author{
RIPTANTI, E. W. $.^{*}-$ MASYHURI, M. ${ }^{2}-$ IRHAM, I. ${ }^{2}-$ SURYANTINI, A. ${ }^{2}-$ MUJIYO, M. ${ }^{3}$ \\ ${ }^{1}$ Agribusiness Department, Faculty of Agriculture, Universitas Sebelas Maret, Surakarta, Indonesia \\ ${ }^{2}$ Agribusiness Department, Faculty of Agriculture, Universitas Gadjah Mada, Yogyakarta, Indonesia \\ ${ }^{3}$ Department of Soil Science, Faculty of Agriculture, Universitas Sebelas Maret, Surakarta, Indonesia \\ *Corresponding author \\ e-mail: erlynawida@staff.uns.ac.id \\ (Received $3^{\text {rd }}$ Aug 2018; accepted $5^{\text {th }}$ Oct 2018)
}

\begin{abstract}
Food insecurity is still a major issue in developing countries, like Indonesia, particularly in East Nusa Tenggara Province. 11 of 21 districts in this province are facing food insecurity. Therefore, efforts should be made to alleviate food insecurity in the community. One way is developing leading food commodities based on local wisdom. The aim of this study is to find a method for developing leading food commodities based on local wisdom, which can be applied in East Nusa Tenggara Province. This study uses secondary data taken and reviewed by the government. The data show that agricultural commodity cultivation the food-insecure area in East Nusa Tenggara is not specialized in certain agricultural commodities, meaning various agricultural commodities are available in various districts and they are not concentrated into a certain district. The availability of commodities is relatively spreading in various districts and is not concentrated in a certain district, although each district has particular leading commodities. Paddy can be cultivated in every food-insecure district except for the East and West Manggarai districts. It depends on the climatic conditions, temperature, humidity and the effort to procure adequate means of irrigation. Upland paddy "gogo", cassava, corn, soybeans, peanuts and sweet potatoes can be cultivated in all district by adjusting appropriate cropping patterns during rainfall, temperature, and humidity suitable for the commodities. The improvement of food security in order to overcome food insecurity in 11 of 21 districts in East Nusa Tenggara should be done by promoting local wisdom, especially by the development of agricultural cultivation based on customs and local potency. Increased focus needs to be put on local potentials regarding the development of staple foods, with the support of all parties and active participation of the community.
\end{abstract}

Keywords: staple food, upland paddy "gogo", agricultural cultivation, cropping patterns

\section{Introduction}

The problem of food insecurity is closely related to poverty (Sue and Smith, 2001). Poverty in East Nusa Tenggara (NTT) is caused by the condition of natural resources and the dry climate (Consultative Group of International Agricultural Research (CGIAR), 2013; Natamba et al., 2018). The poverty rate in 2010 to 2017 has always been higher than the national poverty rate. The poverty line is used as a boundary to determine whether a person is categorized poor. The poverty line component consists of the Food Poverty Line and Non-Food Poverty Line. Food commodities in contributing poverty line is greater than that of non-food commodities (housing, clothing, education, and health). The Food Poverty Line is the minimum food expenditure requirement equivalent to 2,100 kilocalories per capita per day. The basic food commodities are represented by 52 types of commodities, such as grains, tubers, fish, meat, eggs and milk, vegetables, beans, fruits, oils, fats, etc (BPS $\left.{ }^{c}, 2017\right)$. 
The expenditure to meet food needs is a basic requirement that must be met regardless of one's income level. Economists portrait the economic prosperity level of the community $\left(\mathrm{BPS}^{\mathrm{b}}, 2016\right)$ by using food groups as indicators. Engels' Law states that if the tastes are the same, the percentage of expenditure on food will be decreasing along with the increasing income (Nicholson, 1992). Figure 1 shows that the expenditure of the population in rural areas of NTT on food is approximately $60 \%$ of its total income, while in urban areas it is about $45 \%$ of its total income. Population expenditure on food in rural areas is greater than that of urban areas although the agricultural land is wider. This indicates that agricultural land has not been managed at an optimum level.

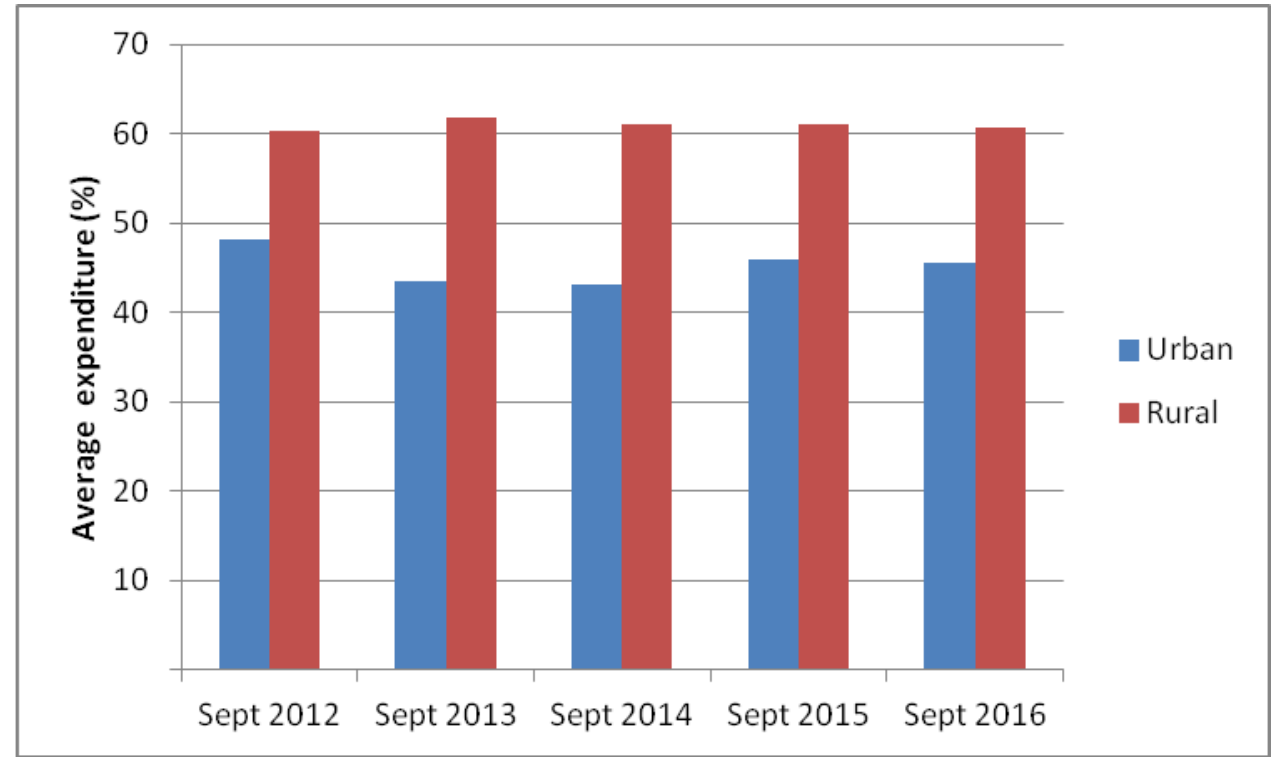

Figure 1. Percentage of average monthly expenditure per capita for food in NTT

The level of adequacy of energy and protein consumption can be used as an indicator to show the nutritional condition of the community, as well as to see to which extent the development in food, agriculture, health and social economy sectors is successful. According to Widyakarya Nasional Pangan dan Gizi (WNPG), the limit of the sufficiency standard of calories and protein consumption by Indonesian people are 2,150 kilocalories ( $\mathrm{kcal}$ ) and $57 \mathrm{~g}$ of protein per capita per day. This standard is certainly based on individual, instead of domestic approach. The average of daily consumption of calories and protein per capita per day in NTT (BPS $\left.{ }^{b}, 2016\right)$ are presented in Figure 2.

Figure 2 indicates that the average consumption of calories and protein per capita per day in NTT are lower than the standard limit for the adequacy of calories and protein intake. In the long run, this will worsen the physical and health condition of the population in NTT.

Many factors can affect household vulnerability to food insecurity. These factors are categorized according to their relation with three dimensions of food security, which are food availability, food access and utilization of nutrients in food. Based on the Map of Food Security in NTT, sub-districts included in Priority 1 are those with the tendency to have higher levels of vulnerability than sub-districts with higher priority. Thus, Priority 
6 include sub-districts that tend to have higher food security. Sub-districts with Priority 1, 2 and 3 have tendencies to be more vulnerable to food insecurity and those with Priority 4, 5 and 6 are considered as food-secure categories. Sub-districts with Priority 1,2 and 3 are mapped in red gradations and Priority 4, 5 and 6 in green color gradations.

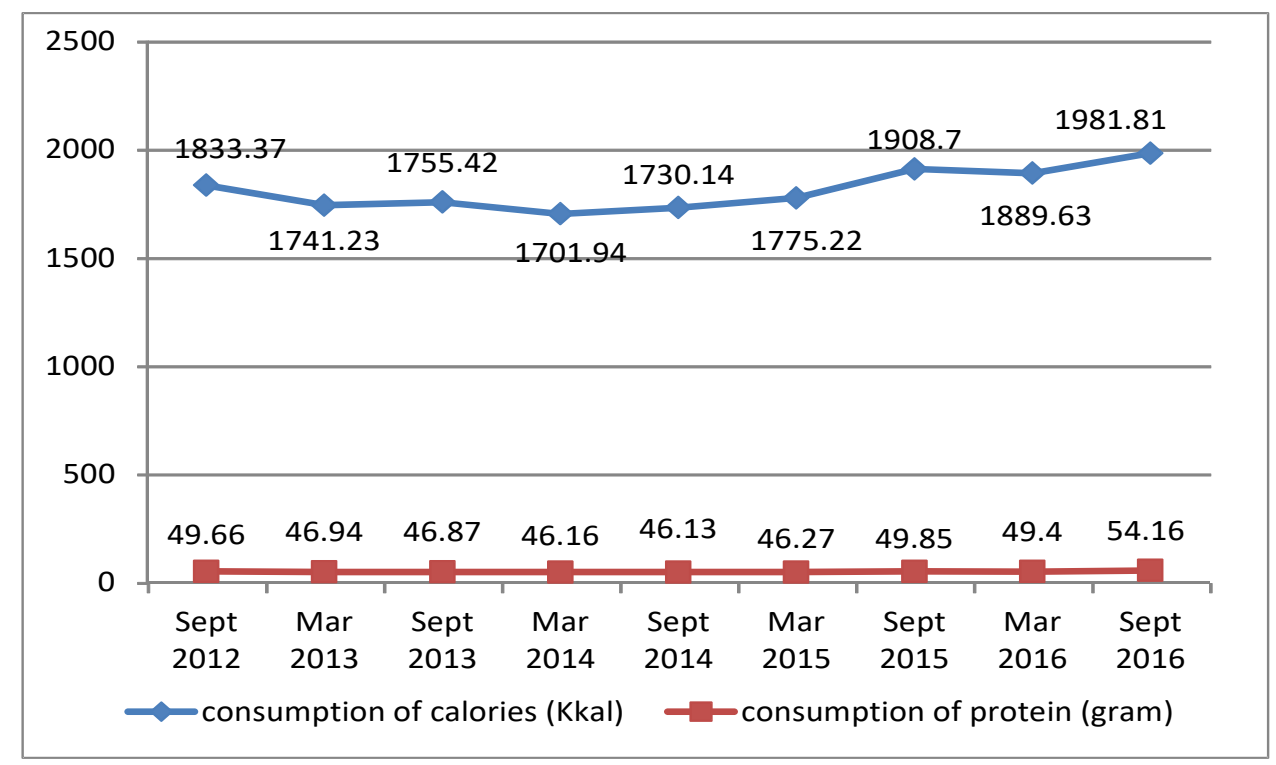

Figure 2. The average consumption of calories and protein per capita per day

Based on the analysis of food security composite in Figure 3, 300 sub-districts in NTT are clustered into six priority groups as follows: 14 sub-districts in Priority 2 (5\%), 67 sub-districts in Priority 3 (22\%), 74 sub-districts in Priority 4 (25\%), 138 subdistricts in Priority $5(46 \%)$ and 7 sub-districts in Priority $6(2 \%)$. There is no subdistrict considered as Priority 1. Table 1 shows that the total of sub-district grouped in Priority 1 to 3 (most vulnerable to food insecurity) are 81 .

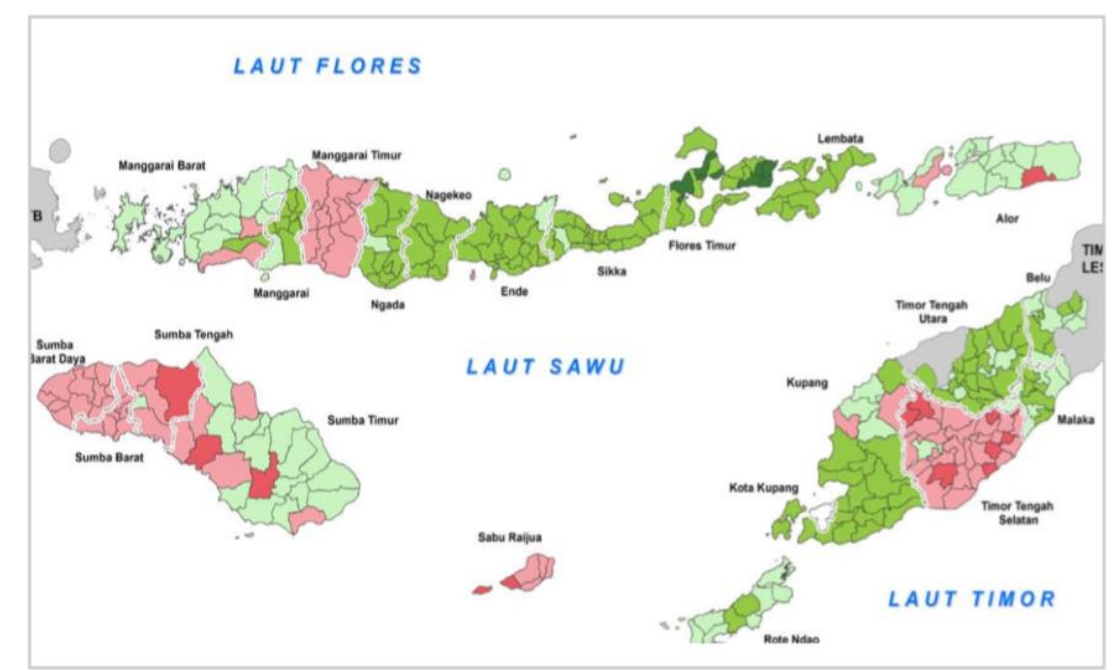

Figure 3. Food security maps in NTT. (Sources: Dewan Ketahanan Pangan NTT and World Food Program, 2015) 
Table 1. Distribution of inter-district priority groups. (Source: Dewan Ketahanan Pangan NTT and World Food Program, 2015)

\begin{tabular}{c|c|c|c|c|c|c|c}
\hline \multirow{2}{*}{ No } & \multirow{2}{*}{ District } & \multicolumn{6}{|c}{ Number of sub-district in priority (\%) } \\
\cline { 3 - 8 } & Priority 1 & Priority 2 & Priority 3 & Priority 4 & Priority 5 & Priority 6 \\
\hline 1 & West Sumba & - & - & 9 & - & - & - \\
2 & East Sumba & - & 14 & 7 & 20 & - & - \\
3 & Kupang & - & - & 3 & 4 & 14 & - \\
4 & South Central Timor & - & 57 & 34 & 1 & - & - \\
5 & North Central Timor & - & - & - & 5 & 14 & - \\
6 & Belu & - & - & - & 8 & 4 & - \\
7 & Alor & - & 7 & 3 & 19 & - & - \\
8 & Lembata & - & - & - & - & 7 & - \\
9 & East Flores & - & - & - & - & 9 & 100 \\
10 & Sikka & - & - & - & 3 & 14 & - \\
11 & Ende & - & - & 2 & 3 & 13 & - \\
12 & Ngada & - & - & - & 1 & 8 & - \\
13 & Manggarai & - & - & - & 4 & 6 & - \\
14 & Rote Ndao & - & - & - & 11 & 1 & - \\
15 & West Manggarai & - & - & 2 & 10 & 1 & - \\
16 & Central Sumba & - & 7 & 16 & - & - & - \\
17 & Southwest Sumba & - & - & 5 & 1 & - & - \\
18 & Nagekeo & - & - & - & - & 5 & - \\
19 & East Manggarai & - & - & 13 & - & - & - \\
20 & Sabu Raijua & - & 14 & 6 & - & - & - \\
21 & Malaka & - & - & - & 9 & 4 & - \\
\hline
\end{tabular}

Most of the population in NTT work in the agricultural sector. Approximately $61.65 \%$ of the working population in NTT work in the agricultural sector in 2016, and the percentage dropped to $53.32 \%$ by 2017 . From economic perspective, the agricultural sector contributed with 29.65\% to Gross Regional Domestic Product (GRDP) in 2016 and dropped to $28.89 \%$ to GDP in 2017 (BPS $\left.{ }^{\mathrm{d}}, 2017\right)$. This condition indicates that the economic contribution of the agricultural sector has dropped. On the other hand, this sector has not been able to meet the food needs of its population; there are 81 subdistrict that are vulnerable to food insecurity.

The purpose of this study is to formulate the development of leading food commodities based on local wisdom in food insecurity areas in East Nusa Tenggara, Indonesia. The fulfillment of staple needs is a basic need that must be met for the sake of food security. The community in the food-insecure areas has tried to provide of staple food through its cultivation. However, it is necessary to improve the management to achieve food sovereignty of local communities. Agricultural production seems to hold the key to economic growth and development in the developing nations of the world (Omotoso et al., 2018).

\section{Materials and methods}

\section{Data used for the identification of leading staple food commodities}

Identification of leading staple food commodities was carried out using location quotient (LQ). LQ is a technique known for a relative handful of development professionals. It is one of the most basic analytical tools available for economic 
development researchers/ professionals. LQ is to yield a coefficient or a simple expression of how well a particular industry is represented in a given study region (Miller et al., 1991). This indicator (LQ) is a localization measure, in the sense that it allows us to assess the relative concentration degree of a given activity (i) in a given region $(\mathrm{t})$.

$$
\text { Analytically LQ }=\frac{\mathrm{vi} / \mathrm{vt}}{\mathrm{vi} / \mathrm{Vt}}
$$

vi: Value of agricultural commodities production (i) at district level of food insecurity in NTT.

vt: Value of total agricultural commodities production at district level of food insecurity in NTT.

Vi: Value of agricultural commodities production (i) from all food-insecure districts in NTT.

Vt: Value of total agricultural commodities production from all food-insecure district in NTT.

The reference base is unit. Thus:

$\mathrm{LQ}<1-$ means that sector $i$ in region $t$ is not very significant, and that the region is not particularly specialized in sector $i$;

$\mathrm{LQ}=1-$ in this case the relative importance of sector $i$ in region $t$ equals its importance in the reference region;

$\mathrm{LQ}>1-$ means that sector $i$ in region $t$ plays an important role, and that the region is relatively specialized in sector $i$ (Diniz et al., 2010). Localization quotients are useful tools to characterize regions internally and to compare them both among themselves and to the reference territorial unit (Delgado and Godinho, 2005).

The analysis of the area of leading agricultural commodity base is used to identify the areas that are the basis of the leading agricultural commodities. This analysis uses specialization quotient and location quotient. Special quotient (Ksi) are used to see if a district is specialized in a particular agricultural activity (Djojodipuro, 1992). The value of Ksi is obtained by the following formula:

$$
\mathrm{Ksi}=(\mathrm{vi} / \mathrm{vt})-(\mathrm{Vi} / \mathrm{Vt})
$$

The value of the special quotient is derived from the total of positive values of Ksi. Criteria used is if the Ksi district $\geq 1$ or Ksi $\sim 1$ then a district is specialized in agricultural activities on certain commodities and if Ksi district $\sim 0$ then a district is not specialized in agricultural activities on certain commodities.

Localization Quotients (Lo) are used to determine the agglomeration or extension of a particular commodity in a region or to find out the existence of a concentration of agricultural activity in a district (Djojodipuro, 1992). To calculate the value of location quotient the following equation was used:

$$
\text { Loi }=(\mathrm{vi} / \mathrm{Vi})-(\mathrm{vt} / \mathrm{Vt})
$$

If the value of localization quotient is close to or more than one, the agricultural commodity centers in an area and if the value of localization quotient is near zero point, the agricultural commodity spreads in various areas. The value of Lo in each commodity is obtained by summing the positive Loi from each particular commodity in 
all districts while LQ from each district obtained by summing positive Loi from all agricultural commodities in a particular district. After obtaining the analysis results of the superior commodity from each regency, the climatic conditions are then analyzed to determine the suitability.

\section{Study area}

District categorized in food insecurity areas are district with sub-district in category 2 and or 3, making the total of 11 district (areas mapped with pink gradation to deep red gradation in Figure 3).

The data used in this analysis are secondary data provided by the Central Bureau of Statistics of East Nusa Tenggara (NTT) in 2011-2015, which include data on production, price, and Gross Regional Domestic Revenue (GRDP). The analyzed commodities are limited to staple food such as paddy, upland paddy, corn, soybeans, peanuts, green beans, cassava, and sweet potatoes. In addition, official information from government agency websites is used in result synchronization and the publication of the research results regarding the local wisdoms in NTT.

\section{Geographical and climatic condition}

East Nusa Tenggara belongs to the island province with 1,192 islands. East Nusa Tenggara is geographically located at $8^{\circ}-12^{\circ}$ South Latitude and $118^{\circ}-125^{\circ}$ East Longitude with the total width of $47,931.54 \mathrm{~km}^{2}$. It is a province with flat topography and slightly tilted lands because some parts of the area are hills and mountains (BPS ${ }^{\mathrm{d}}$, 2017). The rain intensity (Figure 4) in the last six years is fluctuating and tends to decrease.

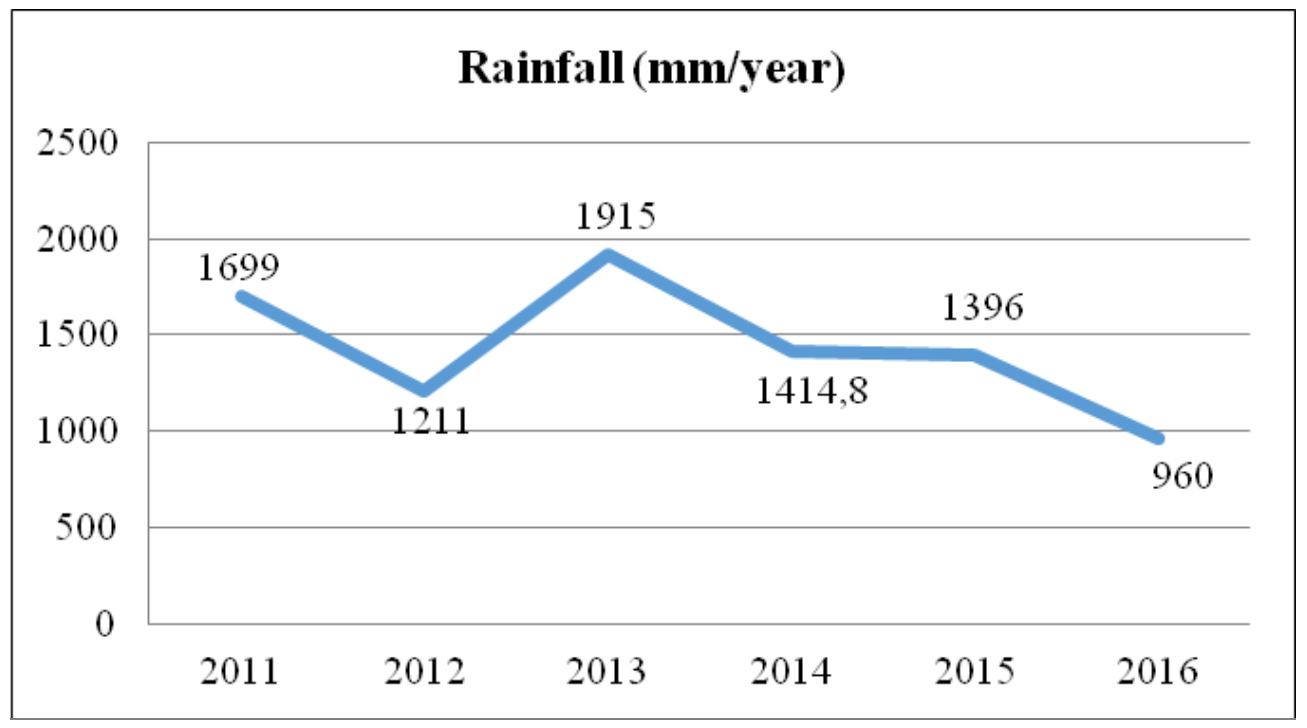

Figure 4. The rain intensity in East Nusa Tenggara in 2011-2016

The climatic conditions of the research location are identified using the climate classification method introduced by Schmidt-Ferguson (1951) by determining the Q ratio. The $\mathrm{Q}$ ratio is determined using the following equation: 


$$
\mathrm{Q}=\frac{\sum \text { average dry months }}{\sum \text { average wet months }} \times 100 \%
$$

A month is categorized as wet month when the rain intensity is $>100 \mathrm{~mm}$, as humid month when the rain intensity is $60-100 \mathrm{~mm}$, and as dry month when the rain intensity is $<60 \mathrm{~mm}$. Based on the value of Q ratio, an area can be classified into eight types, namely type A $0.0 \%<\mathrm{Q}<14.3 \%$ (very wet), B $14.3 \%<\mathrm{Q}<33.3 \%$ (wet), C $33.3 \%<$ $\mathrm{Q}<60.0 \%$ (rather wet), D 60.0\% $<\mathrm{Q}<100 \%$ (normal), E 100\% $<\mathrm{Q}<167 \%$ (rather dry), F 167\% < Q < 300\% (dry), G 300\% < Q < 700\% (very dry), and H Q > 700\% (extraordinarily dry). Based on the calculations, the data shown in Figure 5, East Nusa Tenggara has $\mathrm{Q}$ ratio $=175 \%$ which means it is a dry area.

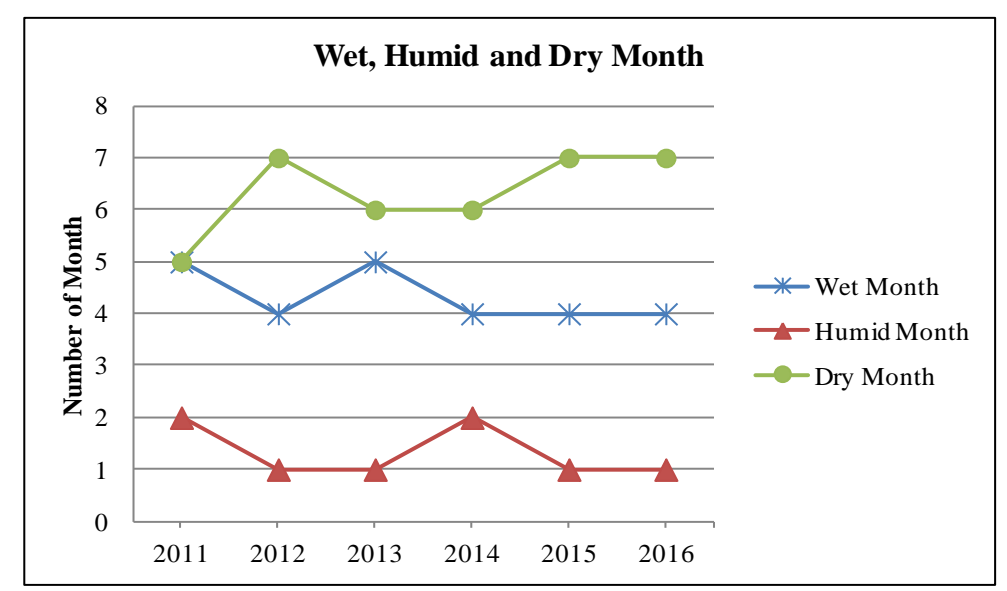

Figure 5. The number of wet months, humid months, and dry months in East Nusa Tenggara

\section{Results}

\section{Determination of staple food commodities priorities}

The development of staple food commodities need to be more organized to suit its potential. Therefore, local governments and communities need to recognize the conditions of the agricultural sector in producing products for public consumption, whether the production of staple food has been able to meet the needs of people in foodinsecure areas or fails to meet the needs of the community and government still have to import from other areas. It is also important to support the right of individual farmers and indigenous communities to continue and develop their sustainable agriculture systems, environmental management practices and livelihoods. The practice of storage, development and exchange of seeds of food crops and medicines should also be concerned. Furthermore, the local food system means empowering the community to protect, conserve and utilize agricultural and other environments to ensure the fulfilment of their food and income needs. Food localization includes changes from dependence on external input and monoculture cultivation system to become selfsufficient in meeting the input needs and diversity of cultivated crops.

Based on the results of Location Quotient analysis to determine the leading staple food commodities in food insecurity areas in NTT, it is found that each district has different leading commodities. The leading agricultural commodities in each foodinsecure district are included in Table 2. 
Table 2. Leading staple food commodities in each food insecurity district in NTT from 20112015

\begin{tabular}{|c|c|c|c|c|c|}
\hline \multirow{2}{*}{ District } & \multicolumn{5}{|c|}{ Leading staple food commodities year } \\
\hline & 2011 & 2012 & 2013 & 2014 & 2015 \\
\hline West Sumba & $\begin{array}{l}\text { Paddy, upland } \\
\text { paddy "gogo" }\end{array}$ & $\begin{array}{l}\text { Paddy, mung } \\
\text { bean }\end{array}$ & $\begin{array}{l}\text { Paddy, peanut, } \\
\text { mung bean }\end{array}$ & Paddy & Paddy, cassava \\
\hline East Sumba & $\begin{array}{l}\text { Paddy, corn, } \\
\text { peanut }\end{array}$ & $\begin{array}{l}\text { Paddy, corn, } \\
\text { peanut }\end{array}$ & $\begin{array}{l}\text { Paddy, upland } \\
\text { paddy "gogo", } \\
\text { peanut }\end{array}$ & $\begin{array}{l}\text { Paddy, peanut, } \\
\text { sweet potato }\end{array}$ & $\begin{array}{l}\text { Upland paddy } \\
\text { "gogo", peanut, } \\
\text { sweet potato }\end{array}$ \\
\hline Kupang & Corn, peanut & $\begin{array}{l}\text { Upland paddy } \\
\text { "gogo", corn, } \\
\text { peanut }\end{array}$ & $\begin{array}{l}\text { Upland paddy } \\
\text { "gogo", peanut, } \\
\text { sweet potato }\end{array}$ & $\begin{array}{c}\text { Peanut, cassava, } \\
\text { sweet potato }\end{array}$ & Paddy, peanut \\
\hline $\begin{array}{l}\text { South Central } \\
\text { Timor }\end{array}$ & $\begin{array}{l}\text { Corn, cassava, } \\
\text { sweet potato }\end{array}$ & $\begin{array}{c}\text { Corn, soy bean, } \\
\text { cassava }\end{array}$ & Corn, soy bean, & $\begin{array}{c}\text { Corn, soy bean, } \\
\text { cassava }\end{array}$ & $\begin{array}{c}\text { Corn, soy bean, } \\
\text { peanut, mung } \\
\text { bean }\end{array}$ \\
\hline Alor & $\begin{array}{l}\text { Upland paddy } \\
\text { "gogo", corn, } \\
\text { cassava }\end{array}$ & $\begin{array}{l}\text { Upland paddy } \\
\text { "gogo", corn, } \\
\text { cassava }\end{array}$ & $\begin{array}{l}\text { Upland paddy } \\
\text { "gogo", corn, } \\
\text { soy bean, mung } \\
\text { bean, sweet } \\
\text { potato }\end{array}$ & $\begin{array}{l}\text { Upland paddy } \\
\text { "gogo", cassava }\end{array}$ & $\begin{array}{l}\text { Upland paddy } \\
\text { "gogo", mung } \\
\text { bean, cassava }\end{array}$ \\
\hline Ende & $\begin{array}{l}\text { Paddy, upland } \\
\text { paddy "gogo", } \\
\text { cassava, sweet } \\
\text { potato }\end{array}$ & $\begin{array}{l}\text { Paddy, upland } \\
\text { paddy "gogo", } \\
\text { cassava }\end{array}$ & $\begin{array}{l}\text { Paddy, upland } \\
\text { paddy "gogo", } \\
\text { soy bean, sweet } \\
\text { potato }\end{array}$ & $\begin{array}{l}\text { Paddy, upland } \\
\text { paddy "gogo", } \\
\text { cassava, sweet } \\
\text { potato }\end{array}$ & $\begin{array}{l}\text { Paddy, upland } \\
\text { paddy "gogo", } \\
\text { mung bean, } \\
\text { cassava, sweet } \\
\text { potato }\end{array}$ \\
\hline $\begin{array}{c}\text { West } \\
\text { Manggarai }\end{array}$ & $\begin{array}{l}\text { Paddy, soy bean, } \\
\text { mung bean, } \\
\text { sweet potato }\end{array}$ & $\begin{array}{l}\text { Paddy, mung } \\
\text { bean }\end{array}$ & $\begin{array}{l}\text { Paddy, sweet } \\
\text { potato }\end{array}$ & $\begin{array}{l}\text { Paddy, soy } \\
\text { bean, sweet } \\
\text { potato }\end{array}$ & $\begin{array}{l}\text { Paddy, soy bean, } \\
\text { mung bean }\end{array}$ \\
\hline Central Sumba & $\begin{array}{l}\text { Paddy, soy bean, } \\
\text { mung bean, } \\
\text { sweet potato }\end{array}$ & $\begin{array}{l}\text { Upland paddy } \\
\text { "gogo", corn, soy } \\
\text { bean, mung bean }\end{array}$ & $\begin{array}{l}\text { Paddy, soy } \\
\text { bean, sweet } \\
\text { potato }\end{array}$ & $\begin{array}{l}\text { Paddy, soy } \\
\text { bean, peanut, } \\
\text { sweet potato }\end{array}$ & $\begin{array}{c}\text { Paddy, cassava, } \\
\text { sweet potato }\end{array}$ \\
\hline $\begin{array}{l}\text { Southwest } \\
\text { Sumba }\end{array}$ & $\begin{array}{l}\text { Upland paddy } \\
\text { "gogo", soy } \\
\text { bean, cassava, } \\
\text { sweet potato }\end{array}$ & Paddy, cassava & $\begin{array}{l}\text { Upland paddy } \\
\text { "gogo", soy } \\
\text { bean }\end{array}$ & $\begin{array}{l}\text { Upland paddy } \\
\text { "gogo", corn }\end{array}$ & $\begin{array}{l}\text { Upland paddy } \\
\text { "gogo", corn, } \\
\text { cassava }\end{array}$ \\
\hline $\begin{array}{c}\text { East } \\
\text { Manggarai }\end{array}$ & $\begin{array}{l}\text { Paddy, mung } \\
\text { bean }\end{array}$ & Paddy & $\begin{array}{l}\text { Paddy, soy } \\
\text { bean, mung } \\
\text { bean, }\end{array}$ & $\begin{array}{l}\text { Paddy, mung } \\
\text { bean, sweet } \\
\text { potato }\end{array}$ & $\begin{array}{l}\text { Paddy, sweet } \\
\text { potato }\end{array}$ \\
\hline Sabu Raijua & $\begin{array}{l}\text { Peanut, mung } \\
\text { bean }\end{array}$ & $\begin{array}{l}\text { Peanut, mung } \\
\text { bean }\end{array}$ & $\begin{array}{l}\text { Peanut, mung } \\
\text { bean }\end{array}$ & $\begin{array}{l}\text { Corn, peanut, } \\
\text { mung bean }\end{array}$ & $\begin{array}{l}\text { Peanut, mung } \\
\text { bean }\end{array}$ \\
\hline
\end{tabular}

\section{Determination of areas specialized in leading staple food commodities}

Specialization Quotient (KS) is used to see if a district is specialized in a particular agricultural activity or to see whether or not a particular agricultural commodity is specialized in a district. For the results of data analysis see Table 3.

The average value of Ksi as a whole is $\sim 0$. This means that there is no specialization in agricultural activities so there are no specialization of specific agricultural commodities. With the absence of specialization of agricultural activities in a certain 
agricultural commodity, it is possible that commodities of staple food crops can be cultivated in various districts in NTT.

Table 3. Value of specialization quotient in each food-insecure district in NTT from 20112015

\begin{tabular}{c|c|c|c|c|c}
\hline \multirow{2}{*}{ District } & \multicolumn{5}{|c}{ Value of special quotient } \\
\cline { 2 - 6 } & $\mathbf{2 0 1 1}$ & $\mathbf{2 0 1 2}$ & $\mathbf{2 0 1 3}$ & $\mathbf{2 0 1 4}$ & $\mathbf{2 0 1 5}$ \\
\hline West Sumba & 0.19584 & 0.09161 & 0.14045 & 0.15634 & 0.19422 \\
East Sumba & 0.16897 & 0.12898 & 0.13566 & 0.11149 & 0.07923 \\
Kupang & 0.09560 & 0.07765 & 0.06396 & 0.04673 & 0.05149 \\
South Central Timor & 0.29377 & 0.31861 & 0.42061 & 0.38762 & 0.40853 \\
Alor & 0.24304 & 0.25715 & 0.31951 & 0.42115 & 0.44900 \\
Ende & 0.15481 & 0.25808 & 0.23558 & 0.25800 & 0.27226 \\
West Manggarai & 0.29057 & 0.48316 & 0.48127 & 0.47634 & 0.47996 \\
Central Sumba & 0.27011 & 0.34700 & 0.08576 & 0.19144 & 0.06385 \\
Southwest Sumba & 0.20736 & 0.26994 & 0.14967 & 0.28957 & 0.22449 \\
East Manggarai & 0.42555 & 0.41465 & 0.32463 & 0.33371 & 0.40123 \\
Sabu Raijua & 0.58179 & 0.43549 & 0.45691 & 0.47691 & 0.30326 \\
\hline
\end{tabular}

The value of positive Specialization Quotient shows that a district has a comparative advantage to produce agricultural commodities. The low value of KS is because most of the commodity produced has negative Ksi value and negative Ksi value is due to the fact that the productivity value in district level is lower compared to the production value in provincial level for the same commodity. The lower production in district level compared to provincial level is caused by the fact that many districts produce the same commodities with high production value (which causes the commodity also become leading commodity).

\section{Determination of agglomeration or distribution level of leading staple food commodities}

Localization Quotient is used to determine the agglomeration or spreading level of a particular commodity in a region. If the value of Localization Quotient (Lo) $\sim 1$ or Lo > 1 then the commodity is concentrated in a district in NTT, and if Lo $<0.5$ then the commodity is spread in some districts in NTT.

Table 4 shows that most Lo is higher than 0.5 which indicates the spreading of commodities in some district in NTT. By knowing the value of Lo, it is possible to estimate the location that has potential for the development of a certain agricultural commodities that can be used as the basis of agricultural development plan and implementation of agricultural policy plan. Thus, agricultural development can focus, grow and develop optimally. In other words, the determination of potential sites based on Lo analysis can provide an initial picture of the potential of agricultural activities in a district compared to other districts. Thus, it is expected to be a reference for developing regional development plans related especially to the agricultural sector and the development of regional economic in general as well. 
Table 4. Value of local quotient in every district in food-insecure areas in NTT from 20112015

\begin{tabular}{c|c|c|c|c|c}
\hline \multirow{2}{*}{ District } & \multicolumn{5}{|c}{ Value of local quotient } \\
\cline { 2 - 6 } & $\mathbf{2 0 1 1}$ & $\mathbf{2 0 1 2}$ & $\mathbf{2 0 1 3}$ & $\mathbf{2 0 1 4}$ & $\mathbf{2 0 1 5}$ \\
\hline West Sumba & 0.03094 & 0.02852 & 0.10160 & 0.02526 & 0.04463 \\
East Sumba & 0.16882 & 0.10654 & 0.14339 & 0.21576 & 0.31587 \\
Kupang & 0.35159 & 0.36747 & 0.18665 & 0.19733 & 0.19796 \\
South Central Timor & 0.27048 & 0.27632 & 0.28082 & 0.26993 & 0.31134 \\
Alor & 0.07858 & 0.09195 & 0.09449 & 0.13308 & 0.16735 \\
Ende & 0.02679 & 0.05458 & 0.25322 & 0.07266 & 0.10166 \\
West Manggarai & 0.20471 & 0.15779 & 0.16652 & 0.63531 & 1.05128 \\
Central Sumba & 0.21252 & 0.79200 & 0.08569 & 0.14780 & 0.03547 \\
Southwest Sumba & 0.49706 & 0.06723 & 0.23520 & 0.35100 & 0.25058 \\
East Manggarai & 0.13360 & 0.13708 & 0.18075 & 0.22387 & 0.29831 \\
Sabu Raijua & 0.32955 & 0.52879 & 0.53061 & 0.57237 & 0.31480 \\
\hline
\end{tabular}

\section{Discussion}

\section{Development of leading staple food commodities based on climate conditions}

Strong agricultural adaptation measures are the keys to develop food production on dry land, but it depends on the financial policy and support. Because agriculture holds so many answers to the challenges posed by the changing weather patterns, it makes sense that this sector and research related to this sector take part in climate change talks (FAO, 2004).

The development of leading staple food commodities is important considering climate factors like rainfall, air temperature and humidity. One aspect of commodity development is to provide suitable land for planting, and one aspect to consider is the characteristic of agro-climate (Mujiyo et al., 2017; Varcoe, 1990). Climatic conditions such as drought, high or low temperature and high humidity can affect the quality and quantity of agricultural products (BPTP Maluku, 2017). Climate conditions that are less suitable to the growth of plants can also spur the growth of plant disease that can damage the plants (Gang et al., 2013; Ploetz, 2015). One of the strategies that can be implemented is evaluating land suitability of food crop seen from its agro-climate conditions such as rainfall, temperature and humidity. The results of land suitability evaluation show which areas are suitable for the development of leading food commodities. Evaluation of land suitability is done by matching the climatic condition with the requirement for leading food commodities to grow. Such terms refer to Ritung et al. (2011) and Wahyunto et al. (2016). Growing condition of agro-climatic leading food commodities are presented in Table 5. Agro-climate data source (rainfall, temperature, humidity) from Central Bureau of Statistics (BPS) East Nusa Tenggara in 2015 (BPS ${ }^{\text {a }, 2015) . ~}$

When land suitability level is considered 'suitable' (S1), it means that climatic conditions are not a factor inhibiting plant growth and do not significantly affect the productivity on the land. When land suitability level is considered 'enough' (S2), it means that climatic conditions can affect land productivity. When land suitability level 
is considered 'marginally suitable' (S3), it means that climatic conditions become a difficult inhibiting factor and require a large input to overcome. When land suitability level is considered 'unsuitable' $(\mathrm{N})$, it means that climatic conditions are a severe inhibiting factor and hard to overcome. The development of leading staple food commodities should pay more attention to the suitability of climatic conditions, as shown in Table 6, so that the production is optimal.

Table 5. Agro-climatic requirement for leading staple food commodity to grow

\begin{tabular}{|c|c|c|c|c|}
\hline \multirow{2}{*}{$\begin{array}{l}\text { Agro-climatic } \\
\text { characteristics }\end{array}$} & \multicolumn{4}{|c|}{ Agro-climatic requirement } \\
\hline & Paddy & Upland paddy & Corn & Soybean \\
\hline \multicolumn{5}{|l|}{ Temperature (tc) } \\
\hline \multirow{4}{*}{$\begin{array}{c}\text { Average } \\
\text { temperature }\left({ }^{\circ} \mathrm{C}\right)\end{array}$} & S1: $24-29$ & S1: $22-25$ & S1: $20-26$ & S1: $23-25$ \\
\hline & S2: $22-24$ or $29-32$ & S2: $25-27$ or $20-22$ & S2: $26-30$ & S2: $20-23$ or $25-28$ \\
\hline & S3: $18-22$ or $32-35$ & S3: $27-29$ or $18-20$ & S3: $16-20$ or $30-32$ & S3: $18-20$ or $28-32$ \\
\hline & $\mathrm{N}:<18$ or $>35$ & $\mathrm{~N}:<18$ or $>29$ & $\mathrm{~N}:<16$ or $>32$ & $\mathrm{~N}:<18$ or $>32$ \\
\hline \multicolumn{5}{|c|}{ Water availability(wa) } \\
\hline \multirow{4}{*}{ Rainfall(mm/year) } & & $\mathrm{S} 1: 1,500-2,000$ & S1: $900-1,200$ & $\mathrm{~S} 1: 350-1,100$ \\
\hline & & $\begin{array}{c}\mathrm{S} 2: \begin{array}{c}1,000-1,500 \\
2,000-2,500\end{array}\end{array}$ & $\begin{array}{c}\mathrm{S} 2: 1,200-1,600 \text { or } \\
500-900\end{array}$ & $\begin{array}{c}\text { S2: } 180-250 \text { or } \\
1,600-1,900\end{array}$ \\
\hline & & $\begin{array}{c}\text { S3: } 700-1,000 \text { or } \\
2,500-3,000\end{array}$ & $\begin{array}{c}\mathrm{S} 3:>1,600 \text { or } \\
300-500\end{array}$ & $\begin{array}{c}\text { S3: } 250-350 \text { or } \\
1,100-1,600\end{array}$ \\
\hline & & $\mathrm{N}:<700$ or $>3,000$ & $\mathrm{~N}:<300$ & $\mathrm{~N}:<180$ or $>1,900$ \\
\hline \multirow{4}{*}{ Humidity (\%) } & $\mathrm{S} 1: 33-90$ & & $\mathrm{~S} 1:>42$ & S1: $24-80$ \\
\hline & S2: 30-33 & & S2: $36-42$ & $\mathrm{~S} 2: 20-24$ or $80-85$ \\
\hline & $\mathrm{S} 3:<30$ or $>90$ & & S3: $30-36$ & $\mathrm{~S} 3:<20$ or $>85$ \\
\hline & $\mathrm{N}:-$ & & $\mathrm{N}:<30$ & $\mathrm{~N}:-$ \\
\hline \multirow{2}{*}{$\begin{array}{l}\text { Agro-climatic } \\
\text { characteristic }\end{array}$} & \multicolumn{4}{|c|}{ Agro-climatic requirement } \\
\hline & Mung bean & Peanut & Sweet potato & Cassava \\
\hline \multirow[t]{2}{*}{ Temperature (tc) } & & & & \\
\hline & S1: $12-24$ & S1: $25-27$ & S1: $22-25$ & S1: \\
\hline \multirow{3}{*}{$\begin{array}{c}\text { Average } \\
\text { temperature }\left({ }^{\circ} \mathrm{C}\right)\end{array}$} & S2: $24-27$ or $10-12$ & S2: $20-25$ or $27-30$ & S2: $25-30$ or $20-22$ & S2: $28-30$ \\
\hline & S3: $27-30$ or $10-12$ & S3: $18-20$ or $30-34$ & S3:18-20 or $30-35$ & S3:18-20 or $30-35$ \\
\hline & $\mathrm{N}:>30$ or $<8$ & $\mathrm{~N}:<18$ or $>34$ & $\mathrm{~N}:<18$ or $>35$ & $\mathrm{~N}:<18$ or $>35$ \\
\hline \multirow[t]{3}{*}{ Water availability(wa) } & & & & \\
\hline & S1: 350-600 & S1: 400-1,100 & $\mathrm{S} 1: 800-1,500$ & $\mathrm{~S} 1: 1,000-2,000$ \\
\hline & $\begin{array}{c}\mathrm{S} 2: 600-1,000 \text { or } \\
300-350\end{array}$ & $\begin{array}{c}\text { S2: } 1,100-1,600 \text { or } \\
300-400\end{array}$ & $\begin{array}{c}\text { S2: } 600-800 \text { or } \\
1.500-2.500\end{array}$ & $\begin{array}{c}\mathrm{S} 2: 600-1,000 \text { or } \\
2,000-3,000\end{array}$ \\
\hline \multirow[t]{2}{*}{ Rainfall(mm/year) } & $\begin{array}{c}\text { S3: > 1,000 or } \\
230-500\end{array}$ & $\begin{array}{c}\text { S3: } 1,600-1,900 \text { or } \\
200-300\end{array}$ & $\begin{array}{l}\text { S3: } 400-600 \text { or } \\
2,500-4,000\end{array}$ & $\begin{array}{c}\text { S3: } 500-600 \text { or } \\
3,000-4,000\end{array}$ \\
\hline & $\mathrm{N}:<250$ & $\mathrm{~N}:>1,900$ or $<200$ & $\begin{array}{c}\mathrm{N}:<400 \text { or }> \\
4,000\end{array}$ & $\mathrm{~N}:<500$ or $>4,000$ \\
\hline \multirow{4}{*}{ Humidity (\%) } & $\mathrm{S} 1: 42-75$ & $\mathrm{~S} 1: 50-80$ & $\mathrm{~S} 1:<75$ & \\
\hline & S2: $36-42$ or $75-90$ & $\mathrm{~S} 2:>80$ or $<50$ & S2: $75-85$ & \\
\hline & S3: $30-36$ or $>90$ & $\mathrm{~S} 3:>80$ or $<50$ & $\mathrm{~S} 3:>85$ & \\
\hline & $\mathrm{N}:<30$ & $\mathrm{~N}:-$ & $\mathrm{N}:-$ & \\
\hline
\end{tabular}

The requirements of growing food commodities refer to Ritung et al. (2011) and Wahyunto et al. (2016) S1: Suitable; S2: Suitable enough; S3: Marginally suitable; N: Unsuitable 
Table 6. Appropriate commodities developed by each food-insecure district in NTT based on weather condition. (Source: Land suitability evaluation)

\begin{tabular}{|c|c|c|c|c|}
\hline \multirow[b]{2}{*}{ District } & \multicolumn{4}{|c|}{ Suitability class for developed food commodity } \\
\hline & Suitable (S1) & \begin{tabular}{|c|} 
Suitable enough \\
(S2)
\end{tabular} & \begin{tabular}{|c|} 
Marginally suitable \\
(S3)
\end{tabular} & Unsuitable (N) \\
\hline West Sumba & Paddy, Peanut & $\begin{array}{l}\text { Corn, Soy bean, } \\
\text { Mung bean, } \\
\text { Cassava, Sweet } \\
\text { potato }\end{array}$ & Upland paddy & - \\
\hline East Sumba & Paddy, Peanut & $\begin{array}{l}\text { Corn, Soy bean, } \\
\text { Mung bean, } \\
\text { Cassava, Sweet } \\
\text { potato }\end{array}$ & Upland paddy & - \\
\hline Kupang & Paddy, Cassava & $\begin{array}{c}\text { Upland paddy, Corn, } \\
\text { Soy bean, Peanut, } \\
\text { Sweet potato }\end{array}$ & Mung bean & - \\
\hline South Central Timor & Paddy, Cassava & $\begin{array}{l}\text { Upland paddy, Corn, } \\
\text { Soy bean, Peanut, } \\
\text { Sweet potato }\end{array}$ & Mung bean & - \\
\hline Alor & Paddy, Cassava & $\begin{array}{c}\text { Corn, Soy bean, } \\
\text { Peanut, Sweet potato }\end{array}$ & $\begin{array}{c}\text { Upland paddy, Mung } \\
\text { bean }\end{array}$ & - \\
\hline Ende & Paddy & \begin{tabular}{|c|} 
Corn, Soy bean, \\
Peanut, Sweet \\
potato, Cassava \\
\end{tabular} & $\begin{array}{l}\text { Upland paddy, Mung } \\
\text { bean }\end{array}$ & - \\
\hline West Manggarai & - & - & \begin{tabular}{|c|} 
Paddy, Upland paddy, \\
Corn, Mung bean, \\
Sweet potato, \\
Cassava
\end{tabular} & Soy bean, Peanut \\
\hline Central Sumba & Paddy, Peanut & $\begin{array}{l}\text { Corn, Soy bean, } \\
\text { Mung bean, } \\
\text { Cassava, Sweet } \\
\text { potato } \\
\end{array}$ & Upland paddy & - \\
\hline Southwest Sumba & Paddy, Peanut & $\begin{array}{l}\text { Corn, Soy bean, } \\
\text { Mung bean, } \\
\text { Cassava, Sweet } \\
\text { potato } \\
\end{array}$ & Upland paddy & - \\
\hline East Manggarai & - & - & $\begin{array}{c}\text { Paddy, Upland paddy, } \\
\text { Corn, Mung bean, } \\
\text { Sweet potato, } \\
\text { Cassava } \\
\end{array}$ & Soy bean, Peanut \\
\hline Sabu Raijua & $\begin{array}{l}\text { Paddy, Corn, Soy } \\
\text { bean }\end{array}$ & $\begin{array}{l}\text { Peanut, Sweet } \\
\text { potato, Cassava }\end{array}$ & $\begin{array}{c}\text { Upland paddy, Mung } \\
\text { bean, }\end{array}$ & \\
\hline
\end{tabular}

Paddy can be cultivated in almost every food-insecure area in NTT; West Sumba, East Sumba, Kupang, South Central Timor, Alor, Ende, Central Sumba, Southwest Sumba and Sabu Raijua. Meanwhile, in West Manggarai and East Manggarai, the suitability level is lower, and therefore, if paddy is cultivated in this location, it will require higher input. The suitability level is based on the temperature and humidity climate conditions in accordance with adequate procurement of irrigation facilities. Upland paddy/gogo, cassava, corn, soybean, peanut and sweet potato can be cultivated 
in every district by adjusting the appropriate cropping pattern when rainfall, temperature and humidity is suitable with the commodities. West Manggarai and East Manggarai districts require higher inputs for the development of the commodity.

\section{Development of leading staple food commodities based on local wisdom}

Dynamic ecological and environmental change suggest that climate change induced drought events may push dryland systems to cross-biophysical thresholds, causing a long-term drop in agricultural productivity. Therefore, research is required to explore how development strategies and other socioeconomic changes can help livelihoods to become more resilient and robust at a time of growing climatic risk and uncertainty (Lefroy et al., 2000; Evan et al., 2011).

Food security is affected by various factors such as number and growth of population, nutritional adequacy recommendations, and food production, nutritional content of agricultural products, food safety, food distribution, socio-economic, community behavior, nutritional and health status and multi-functional food. Local wisdom serves as a food insecurity mitigation (Reijntjes et al., 1992). Local food wisdom means the provision of guarantees and authority in decision-making at local level involving marginalized groups like farmers and indigenous people and a group of women. This system should be done through structuring the control and management of productive resources such as land, water, seeds, technology, inputs, and capital, making institution more fair, productive and sustainable (Smit and Smithers, 1993). Developing a local food system also means strengthening the base of food sovereignty at local and national level (Witoro, 2003). Therefore, the development of staple food commodities in food security areas in NTT needs to be supported by all parties and the active participation by the community (Van der Werf and Petit, 2002; Rasul and Thapa, 2004; Hurni, 2000).

One of the examples of community active participation is building an embung or water reservoirs, which is one element of local wisdom. Embung in the dryland farming system has a very important role in growing staple food crops that can be used in dry seasons (Mganga et al., 2015). The suitability of climatic condition of superior staple plants in each food-insecure area needs to be supported by establishing a so-called embung.

The other form of local wisdoms of NTT people is the application of mamar and kaliwu systems in managing agricultural land. The mamar system acts as the form of the utilization of the areas surrounding the water springs or village areas to increase the carrying capacity of the environment through mixed planting system of the forestry crops, plantation crops, and food crops. The development of mamar system has proven to be able to preserve water springs in accordance with the needs of the community (Njurumana et al., 2007). Meanwhile, the kaliwu system is the form of land management by the local community for generations, which is integrated with the village areas where various types of plants are cultivated, including productive plants and plants with socio-cultural value. Various types of plants developed include forestry crops, plantation crops, and food crops (Njurumana et al., 2003). By building many embung according to the needs and increasing the application of mamar and kaliwu systems, the cropping index will increase and the risk of failing staple food cultivation can be reduced. At last, the food security in the food-insecure areas will increase. 


\section{Conclusion}

Food insecurity in East Nusa Tenggara Province is not specialized in a certain agricultural commodity so that various agricultural commodities of staple food crops can be cultivated in various districts. Similarly, the presence of commodities is relatively spread in some districts, not centered in a certain district, although each district has its own leading commodity. Paddy can be cultivated in every food-insecure district in NTT except for West Manggarai and East Manggarai districts. This suitability is based on the temperature and humidity climate condition in line with adequate procurement of irrigation facilities. Upland paddy or gogo, cassava, corn, soybean, peanut, and sweet potato can be developed in every district by adjusting the appropriate cropping pattern when the rainfall, temperature and humidity values are appropriate for the commodities. The support of the local wisdom by building many embung according to the need and expanding the application of mamar and kaliwu systems in developing superior staple plants will increase the food security. The development of superior staple food cultivation needs to be studied further regarding its sustainability in agribusiness system so that problem solving in food insecure areas can be more comprehensive.

Acknowledgements. We would like to express our sincere gratitude to Universitas Sebelas Maret for funding this research. We would like to thank Novi Rahmawati Sutopo for her participation in the paper preparation. Our sincere appreciation is also extended to all parties who have provided information to complete this article.

Conflict of interests. The authors declare no conflict of interest.

\section{REFERENCES}

[1] Badan Pusat Statistik ${ }^{\mathrm{a}}$ (2015): Nusa Tenggara Timur dalam Angka Tahun 2015. - Badan Pusat Statistik Nusa Tenggara Timur, Kupang, Indonesia.

[2] Badan Pusat Statistik ${ }^{\mathrm{b}}$ (2016): Ringkasan pola konsumsi penduduk Provinsi Nusa Tenggara Timur September 2016. - Badan Pusat Statiktik Nusa Tenggara Timur, Kupang, Indonesia.

[3] Badan Pusat Statistik ${ }^{\mathfrak{c}}$ (2017): Ringkasan data dan informasi kemiskinan Provinsi Nusa Tenggara Timur 2017. - Badan Pusat Statiktik Nusa Tenggara Timur, Kupang, Indonesia.

[4] Badan Pusat Statistik ${ }^{d}$ (2017): Nusa Tenggara Timur Province in Figures. - Badan Pusat Statiktik Nusa Tenggara Timur, Kupang, Indonesia.

[5] BPTP Maluku (2017): Pengaruh Iklim terhadap pertanian. http://maluku.litbang.pertanian.go.id/index.php/berita/516-pengaruh-iklim-terhadappertanian (accessed on 22 June 2018).

[6] CGIAR Research Program on Dryland Systems (2013): New Research Approaches to Improve Drylands Agriculture to Deliver a More Prosperous Future. - International Center for Agricultural Research in the Dry Areas (ICARDA), Ethiopia.

[7] Delgado, A. P., Godinho, I. M. (2005): Medidas de localização das actividades e de especialização regional, in Compêndio. - De Economia Regional $2^{\text {a }}$ Edição José Costa Coordenador APDR.,Coimbra, pp. 713-732.

[8] Dewan Ketahanan Pangan NTT dan World Food Programme (2015): Peta ketahanan dan kerentanan pangan (FSVA) NTT 2015. - Dewan Ketahanan Pangan NTT dan World Food Programme, Kupang, Indonesia.

[9] Diniz, F., Upadhyay, Vinod. (2010): Productive specialization and regional development at State Level In India. - Regional Science Inquiry Journal II(2): 105-118. 
[10] Djojodipuro, M. (1992): Teori lokasi. - Lembaga Penerbit FE UI, Jakarta, Indonesia.

[11] Evan, D. G. F., Andrew, J., Dougill, Klaus, H., Claire, H. Q., Jan, S., Mette, T. (2011): Assessing vulnerability to climate change in dryland livelihood systems: conceptual challenges and interdisciplinary solutions. - Ecology and Society 16(3): 3.

[12] FAO (2004): Carbon sequestration in dryland soils. http://www.fao.org/docrep/007/y5738e/y5738e00.html (accessed on 21 June 2018).

[13] Gang, G., Bizun, W., Weihong, M., Xiaofen, L., Xiaolin, Y., Chaohua, Z., Jianhong, M., Huicai, Z. (2013): Biocontrol of Fusarium wilt of banana: Key influence factors and strategies. - African Journal of Microbiology Research 7(41): 4835-4843.

[14] Hurni, H. (2000): Assessing sustainable land management (SLM). - Agriculture, Ecosystems \& Environment 81(2): 83-92.

[15] Lefroy, R. D. B., Bechstedt, H. D., Rais, M. (2000): Indicators for sustainable land management based on farmer surveys in Vietnam, Indonesia, And Thailand. Agriculture, Ecosystems \& Environment 81(2): 137-146.

[16] Mganga, K. Z., Musimba, N. K. R., Nyariki, D. M. (2015): Combining sustainable land management technologies to combat land degradation and improve rural livelihoods in semi-arid lands in Kenya. - Environmental Management 56: 1538-1548.

[17] Miller, M. M., Gibson, L. J., Wright, N. G. (1991): Location quotient: A basic tool for economic development analysis. - Economic Development Review 9(2): 65-68.

[18] Mujiyo, Widijanto, H., Herawati, A., Rochman, F., Rafirman, R. (2017): Potensi lahan untuk budidaya pisang di Kecamatan Jenawi Karanganyar. - Caraka Tani: Journal of Sustainable Agriculture 32(2): 142-148.

[19] Natamba, L., Zhang, W., Zhang, J., Zhao, X. (2018): Climate change causing food insecurity in East Africa: traditional and non-traditional strategies to solve the problem. Applied Ecology and Environmental Research 16(3): 2233-2254.

[20] Nicholson, W. (1992): Microeconomic Theory. Fifth Edition. - The Dryden Press, New York.

[21] Njurumana, G. N. D., Mariana, T., Pamungkas, T. Y. (2003): Kajian Penerapan Sistem Kaliwu dalam Pengelolaan Tata Air di Sumba Barat. - Buletin Penelitian Hutan 642. Pusat Penelitian dan Pengembangan Hutan dan Konservasi Alam, Bogor.

[22] Njurumana, G. N. D., Hidayatullah, M., Butarbutar, T. (2007): Condition of soil at mamar and kaliwu system in Timor and Sumba. - Info Hutan V(1): 45-51.

[23] Omotoso, A. B., Daud, A. S., Adebayo, R. A., Omotayo, A. O. (2018): Socioeconomic determinants of rural households' food crop production in Ogun State, Nigeria. - Applied Ecology And Environmental Research 16(3): 3627-3635.

[24] Ploetz, R. C. (2015): Fusarium wilt of banana. - Phytopathology 105(12): 1512-1521.

[25] Rasul, G., Thapa, G. B. (2004): Sustainability of ecological and conventional agricultural systems in Bangladesh: An assessment based on environmental, economic and social perspectives. - Agricultural Systems 79(3): 327-351.

[26] Reijntjes, Z. C., Havekort, B., Water, B. A. (1992): Farming for Future: An Introduction to Low External Input and Sustainable Agriculture. - The MacMillan Press, London, UK.

[27] Ritung, S., Nugroho, K., Mulyani, A., Suryani, E. (2011): Petunjuk teknis evaluasi lahan untuk komoditas pertanian (edisi revisi). - Balai Besar Penelitian dan Pengembangan Sumberdaya Lahan Pertanian, Badan Penelitian dan Pengembangan Pertanian, Bogor, Indonesia.

[28] Schmidt, F. H., Ferguson, J. H. A. (1951): Rainfall Types based on Wet and Dry Period Ratios for Indonesia with Western New Guinea. - Djawatan Meteorologi dan Geofisika. Jakarta.

[29] Smit, B., Smithers, J. (1993): Sustainable agriculture: Interpretations, analyses and prospects. - Canadian Journal of Regional Science 3: 499-524.

[30] Sue, B., Smith, A. (2001): Food security and poverty in Australia- Challenges for dietitians. - Australian Journal of Nutrition and Dietetics 58(3): 150-156. 
[31] Van der Werf, H. M., Petit, J. (2002): Evaluation of the environmental impact of agriculture at the farm level: a comparison and analysis of 12 indicator-based methods. Agriculture, Ecosystems \& Environment 93(1-3): 131-145.

[32] Varcoe, V. J. (1990): A note on the computer simulation of crop growth in agricultural land evaluation. - Soil Use and Management 6: 157-160.

[33] Wahyunto, H., Suryani, E., Tafakresnanto, C., Ritung, S., Mulyani, A., Nursyamsi, D. (2016): Petunjuk teknis pedoman penilaian kesesuaian lahan untuk komoditas pertanian strategis tingkat semi detail skala 1 :50.000. - Balai Besar Penelitian dan Pengembangan Sumberdaya Lahan Pertanian, Badan Penelitian dan Pengembangan Pertanian. Bogor. Indonesia.

[34] Witoro (2003): Menemukan Kembali dan Memperkuat Sistem Pangan Lokal. Lokakarya Forum Pendampingan Petani Regio Gedepala, Sukabumi 2-4 September, Indonesia. 